\title{
而候性鋼さび層の電位による保護性評価*
}

\author{
鹿島和幸**, 原 修一***, 岸川浩史**, 幸 英昭** \\ ** 住友金属工業株式会社 総合技術研究所, \\ *** 住友金属工業株式会社 本社
}

\section{Evaluation of Protective Ability of Rust Layers on Weathering Steels by Potential Measurement*}

\author{
Kazuyuki Kashima**, Shuichi Hara***, Hirofumi Kishikawa** and Hideaki Miyuki** \\ ** Sumitomo Metal Industries Ltd. Corporate Research and Development Laboratories, \\ ***Sumitomo Metal Industries Ltd. Head Office
}

\begin{abstract}
The protective ability of rust layers formed on weathering steels exposed in an industrial region for various periods has been studied by the potential measurement, and the rust composition and structure were also studied. Potential of weathering steel in $0.1 \mathrm{~mol} / \mathrm{L} \mathrm{Na}_{2} \mathrm{SO}_{4}$ solution tends to become noble with exposure time. Potential of weathering steels with rust layers, which were exposed for a long time and had superior atmospheric corrosion resistance, became over $-0.3 \mathrm{~V}$ (vs. SCE). The rust layer possesses the double layer structure composed of inner dark layer of $\alpha-\mathrm{FeOOH}$ and outer bright layer under reflected polarized light, which is observed typically in the protective rust layer. On the other hand, potential of mild steel exposed for a long time is less noble at about $-0.45 \mathrm{~V}$ (vs. SCE). These results mean that potential reflects the difference of characteristic of rust layer. Potential became noble with increasing amount of $\alpha$-FeOOH in rust, which suggests that potential depends on the composition of the rust layer. Furthermore, potential correlates with the ratio of rust composition $\alpha / \gamma^{*}: \alpha-\mathrm{FeOOH} /\left(\gamma-\mathrm{FeOOH}+\beta-\mathrm{FeOOH}+\mathrm{Fe}_{3} \mathrm{O}_{4}\right)$, and potential of $-0.3 \mathrm{~V}$ (vs. SCE) corresponds to $\alpha / \gamma^{*}=2$. Therefore potential as well as the ratio $\alpha / \gamma^{*}$ is able to use for the evaluation of the protective ability of the rust layers formed on weathering steels.
\end{abstract}

Key words : weathering steel, evaluation of protective ability of rust layer, protective rust layer, potential, rust constituent, rust composition

\section{1. 緒言}

近年，鋼構造物のメンテナンス費用削減の観点から， 無塗装使用が可能な耐候性鋼が注目されている. Cr, $\mathrm{Cu}, \mathrm{Ni}$ 等の合金元素を少量含む低合金鋼である耐候性 鋼においては, 大気腐食環境中に長期間暴露され乾湿繰 り返しを受けると, 鋼表面に保護性を有するさび層が形 成され, 以後の腐食が著しく抑制される。このさび層の 防食効果により長期間の使用が可能となる。耐候性鋼は 主として橋梁用材料として使用されるが, 数 10 年以上 もの長期間にわたり使用されるため, その維持管理が重 要となる. 特に橋梁においてはその設置環境は様々で, 部位により降雨による洗い流しの有無, 飛来塩分の堆積 の有無等, 同一橋梁においてもその腐食環境は均一では ない.そのため, 部位によっては保護性を有するさび層 が形成しているが，他の部位では形成されないこともあ る.さらには, 長期間にわたり使用する場合には, 設置 環境自体が変化する場合もある。橋梁の保守点検の立場 からは, さびの保護性を定量的に評価できる方法が必要 となる。従来からさび層の保護性に関しさまざまな評価 法が提案され, 実際に使用されている. 例えば, その場 測定可能なものとしては, 目視によるさび表面の性状評

* 材料と環境'99（千葉, 1999 年) で発表

** $\overline{\mathrm{T}}$ 660-0891 尼崎市扶桑町 1-8 (1-8, Fuso-cho, Amagasaki, 6600891 Japan)

*** ₹ 541-0041 大阪市中央区北浜 4-5-33 (4-5-33, Kitahama, Chuoku, Osaka, 541-0041 Japan)
価, 板厚測定, さび層の活性点を観察するフェロキシル 試験 ${ }^{1)}$ ，および交流インピーダンス法によりさび層のイ オン透過抵抗を測定する方法2),3) 等がある。一方，その 場測定ではないが, 曝露試験片の断面観察によりさび層 の構造を調べる方法4)や腐食量の測定, 採取したさびの $\mathrm{X}$ 線回折による構成物質の定量, その定量結果より計算 されるさび構成比 $\alpha / \gamma^{*}$ (ここで, $\alpha: \alpha-\mathrm{FeOOH}, \gamma^{*}$ : $\left.\gamma-\mathrm{FeOOH}+\beta-\mathrm{FeOOH}+\mathrm{Fe}_{3} \mathrm{O}_{4}\right)$ による評価 ${ }^{5), 6)}$ 等が ある.しかし, 曝露試験片によりさびの保護性を評価す る方法においては, 限られた枚数の試験片では実際の橋 梁の部位による条件の差が反映されにくいことや, 調査 に時間がかかるという問題点がある．その場測定できる 方法については, 測定誤差や測定者間のばらつきがあり 信頼性の点で問題となるため, 一般的に普及していると は言い難い。実際，その場測定可能で定量性があり，か つ簡易で信頼性の高い評価法の確立が求められているの が現状である。

本研究では, そのような要求にこたえるべく, 而候性 鋼の特性が発揮される工業地帯で大気曝露された材料を 用いて，その場測定が可能な電気化学的手法の一つであ る電位測定によるさび層の保護性の評価を試みた7),8),9). また, 電位とさび性状, さび組成との関係についても調 査した.

\section{2. 実 験 方 法}

\section{1 調査サンプル}

工業地帯である兵庫県尼崎市において $0.5 \sim 32$ 年間大 
Table 1 Chemical composition of weathering and mild steels investigated (mass\%).

\begin{tabular}{|c|c|c|c|c|c|c|c|c|}
\hline Steel & $\mathrm{C}$ & $\mathrm{Si}$ & $\mathrm{Mn}$ & $\mathrm{P}$ & $\mathrm{S}$ & $\mathrm{Cu}$ & $\mathrm{Ni}$ & $\mathrm{Cr}$ \\
\hline Weathering stleel & 0.11 & 0.24 & 0.75 & 0.014 & 0.005 & 0.33 & 0.12 & 0.49 \\
\hline Mild steel & 0.12 & 0.32 & 1.47 & 0.023 & 0.004 & - & - & - \\
\hline
\end{tabular}

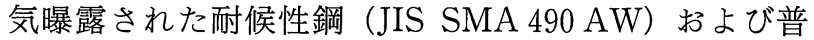
通炭素鋼（SM 490）について調査を行った。 その化学 成分の一例を Table 1 に示す。これらの試験片を，60× $100 \times 3 \quad(\mathrm{~mm})$ の大きさに加工し，ショットブラスト 処理後初期重量を測定した. その後同試験片を水平面よ り南向きに $30^{\circ}$ の傾斜を保って曝露した。所定期間の曝 露試験後それぞれの試験片よりカッターナイフを用いて さびを採取し，X線回折によるさび組成の定量分析を 行った。また，さび採取後の試験片を $10 \%$ クエン酸水 素二アンモニウム溶液に浸漬後ブラシ洗浄してさびを除 去した後重量測定し, 曝露試験前後の重量減より平均の 板厚減少量扔よび腐食速度を算出した。

\section{2 さび層の断面観察}

大気曝露後の一部の試験片については，さび層の断面 性状を観察する目的で, それぞれ $20 \mathrm{~mm}$ 角に切り出し た後常温硬化型エポキシ樹脂に埋め込み, さびが剥離し ないよう注意してさび層断面をエメリー研磨紙＃1000 まで研磨した後, バフ研磨により鏡面に仕上げた。得ら れた試料について, 対空面のさび層断面を光学顕微鏡お よび偏光顕微鏡で観察した。 また, 長期間暴露された試 料については,さび層構成物質の分布を明らかにするた め顕微ラマン分光分析も行った. 入射光源としては $\mathrm{Ar}^{+}$ レーザー（ $(\lambda=514.52 \mathrm{~nm} ）$ を用い, ビーム径は約 2 $\mu \mathrm{m}$ である. この時, 試料の温度上昇を避けるため, 入 射出力を試料表面に扔いて $0.1 \mathrm{~mW}$ 以下となるように 設定した. 分光測定はゼロ分散配置のフィルター分光器 を装備したラマン分光光度形 (日本分光工業(株) 製 NR -1100）で行った。

\section{3 さび構成物質の X線定量分析}

各試験片よりさびを採取し, 内部標準法によるX線定 量分析 ${ }^{10)}$ を行った。内部標準物質としては試薬特級の $\mathrm{KCl}$ あるいは $\mathrm{ZnO}$ 粉末を用い, あらかじめ粒度 $5 \mu \mathrm{m}$ 以下に粉砕した.X線回折用粉末試料はさびに一定重量 比の $\mathrm{KCl}$ あるいは $\mathrm{ZnO}$ を混合し，めのう乳鉢にて粉 砕, 混合して作成した。X線回折測定は理学電機(株)製 RU 200 型を用い, ターゲットとしてはCo を使用, 電 圧一電流は $30 \mathrm{kV}-100 \mathrm{~mA}$ として走查速度 $2^{\circ} / \mathrm{min}$ で行 った。あらかじめ人工さびを用いて作成しておいた検量 線を用いて, 得られたX線回折データよりさび構成物質 である $\alpha-\mathrm{FeOOH}, \beta-\mathrm{FeOOH}, \gamma-\mathrm{FeOOH}$ 打よび $\mathrm{Fe}_{3} \mathrm{O}_{4}$ を定量し，その経年変化を調べた。なお，これら 結晶性物質以外は $\mathrm{X}$ 線的に非晶質なさび物質とみなし た。また，さびの定量分析の結果を $\alpha-\mathrm{FeOOH}, \gamma^{*}$, $\mathrm{X}$ 線的非晶質さびを極とする 3 成分系図で整理すると ともに,さび構成比 $\alpha / \gamma^{* 11)}$ を計算し, 電位との相関性 について調べた。 山下らによると ${ }^{12), 13)}$ ，耐候性鋼におい て最終的に形成される保護性さびは Cr 置換型ゲーサイ 卜 $\left[\alpha-\left(\mathrm{Fe}_{1-x} \mathrm{Cr}_{x}\right) \mathrm{OOH}\right]$ からなるとしており, X 線回
折で定量される $\alpha-\mathrm{FeOOH}$ にはこれも含まれている. そのため, 以下 $\alpha-\mathrm{FeOOH}$ は $\mathrm{Cr}$ 置換型ゲーサイトを含 むゲーサイト型オキシ水酸化鉄の意味で用いることとす る.

\section{4 電位測定}

大気曝露後の試験片より $15 \mathrm{~mm}$ 角を切り出した後, 導電性接着剤を用いて試料端面に銅線を接続して電気的 導通をとり，被測定面積 $1 \times 10^{-4} \mathrm{~m}^{2}$ を残してシリコン 樹脂にて被覆し, 試料電極とした。このようにして作成 した試料について，室温，大気開放条件下において硫酸 ナトリウム溶液中で電位測定を行った。参照電極として は飽和甘こう電極 (SCE) を用い, 試料電極と参照電 極の間の電位差を電位差計（内部抵抗 $10^{11} \Omega$ 以上）を 用いて測定した。また, 硫酸ナトリウム溶液の濃度は 0.001 $1 \mathrm{~mol} / \mathrm{L}$ まで変化させ, 電位の濃度依存性につ いても調査した。なお, 一部の試料については, 溶液中 にAr を吹き込んだ脱気条件下でも電位測定を行った。

\section{3. 結果および考察}

\section{1 大気曝露後のさび層の性状}

\section{1 .1 さび層構成物質}

Fig. 1 は耐候性鋼おるび普通鋼における腐食量の経時 変化である，両鋼種とも腐食速度は経年的に低下する傾 向にあるが，耐候性鋼では数年 10 年以上では腐食量 の増加は極めて少なく, 腐食速度は数 $\mu \mathrm{m} /$ year 以下で あることがわかる. Fig. 2 亿曝露期間 2 年おるび 32 年 の耐候性鋼に抢けるさび層の断面偏光顕微鏡写真を示 す.いずれのサンプルにおいてもさび層の厚みは約 100 $\mu \mathrm{m}$ であり，長期間曝露された耐候性鋼においてもさび 層の厚みは曝露初期と大差ないことがわかる。 2 年曝露 材のさび層には偏光層と消光層が混在しており, 明瞭な 二層構造にはなっていない。一方， 32 年曝露材におい

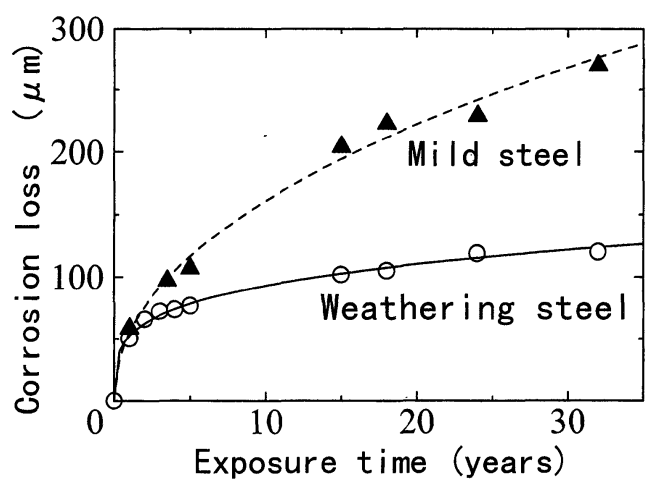

Fig. 1 Change of corrosion loss with exposure time for the weathering and mild steels exposed in industrial region (Amagasaki). 


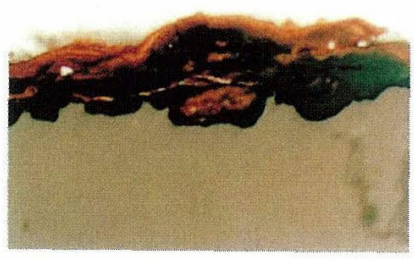

2 years exposure

$100 \mu \mathrm{m}$

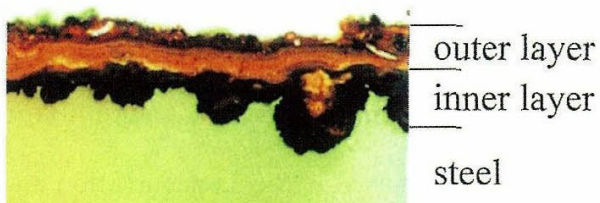

32 years exposure

Fig. 2 Cross sectional observation by reflected polarized light for the rust layer formed on weathering steels exposed for 2 and 32 years.

ては保護性さび層の特徵とされる消光層からな る内層と偏光層加らな外層の二層構造 ${ }^{4}$ 呈 していた。 32 年曝露材のさびのX線回折結果 をFig. 3 に,さびの定量結果を Table 2 に示 す. 32 年曝露材については結晶性のさび物質 としては $\alpha-\mathrm{FeOOH}$ が比較的多く, $\gamma-$ $\mathrm{FeOOH}$ おるび $\mathrm{Fe}_{3} \mathrm{O}_{4}$ が少なく, 非晶質さび が最も多かった。また，Fig. 4 に示すように， 顕微ラマン分光分析法により耐候性鋼の 32 年 曝露材の内層さびを解析した結果, $\alpha-\mathrm{FeOOH}$ が検出された. 以上のようなさび層が二層構造 を呈しかつ内層さび中に $\alpha-\mathrm{FeOOH}$ が存在す るという結果は，三澤らによって報告されてい る 26 年間曝露された耐候性鋼のさび層の調查 結果 ${ }^{13)}$ とも一致する。ただ, 今回の結果では, 32 年曝露材に扝いてもX線的非晶質さびが約 50 mass \%あり，保護性を有すると考兄られる 内層さびは $\alpha-\mathrm{FeOOH} と \mathrm{X}$ 線的非晶質さびと からなると考光られる。なお，このX線的非晶 質さびは, Stratmann ら ${ }^{14)}$ によメスバウア 一分光分析によれば，微細な超常磁性 $\alpha$ $\mathrm{FeOOH}$ であるとされている。これについては 今後さらなる調查が必要である。

\section{1 .2 さび構成物質の経時変化}

Fig. 5 は, 各種期間大気曝露された耐候性䤱に形成し たさび層の構成物質のX線回折による定量結果を, $\gamma-\mathrm{FeOOH}+\beta-\mathrm{FeOOH}+\mathrm{Fe}_{3} \mathrm{O}_{4}, \mathrm{X}$ 線的非晶質さび, 抒よび $\alpha-\mathrm{FeOOH}$ の 3 極からなる 3 成分系睬にプロッ

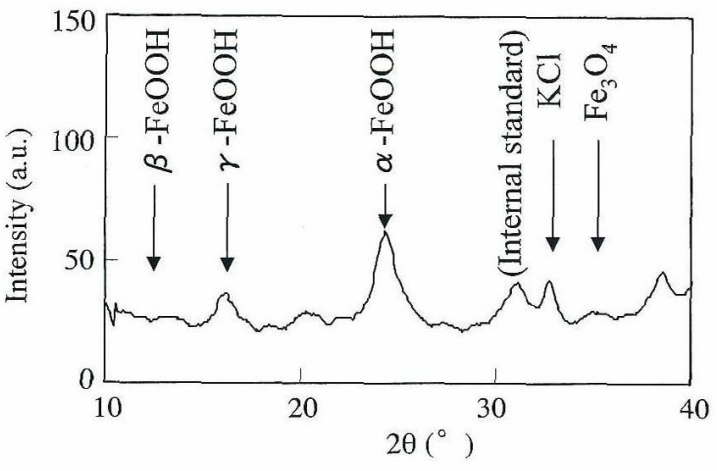

Fig. 3 X-ray diffraction pattern of the rust formed on weathering steel exposed for 32 years by internal standard method.

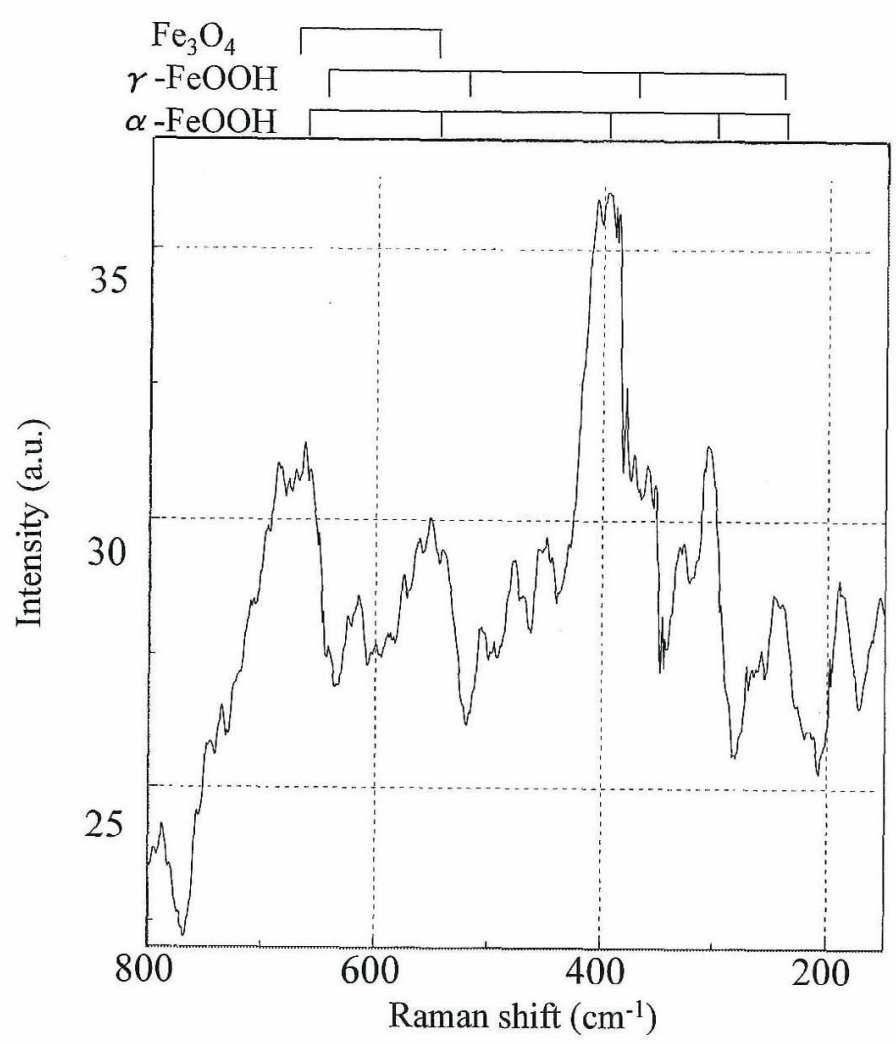

Fig. 4 Raman spectrum for inner rust layer formed on weathering steel exposed for 32 years.

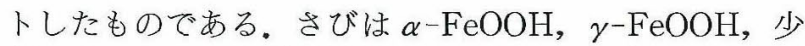
量の $\mathrm{Fe}_{3} \mathrm{O}_{4}$, および $50 \%$ 程度の非晶質さびから構成さ れており，いずれのサンプルについても $\beta-\mathrm{FeOOH}$ 検出されなかった。さび構成物質の経年変化として，X 線的非晶質さびを主体として，初期に $\gamma$ - FeOOH が多 い状態から経年的に $\gamma-\mathrm{FeOOH}$ が減少し $\alpha-\mathrm{FeOOH}$ が

Table 2 Composition of the rust layer formed on weathering steel exposed for 32 years by X-ray diffraction analysis (mass\%).

\begin{tabular}{|c|c|c|c|c|}
\hline$\alpha-\mathrm{FeOOH}$ & $\beta-\mathrm{FeOOH}$ & $\gamma-\mathrm{FeOOH}$ & $\mathrm{Fe}_{3} \mathrm{O}_{4}$ & amorphous substance \\
\hline 31.8 & 0 & 8.4 & 6.7 & 53.1 \\
\hline
\end{tabular}




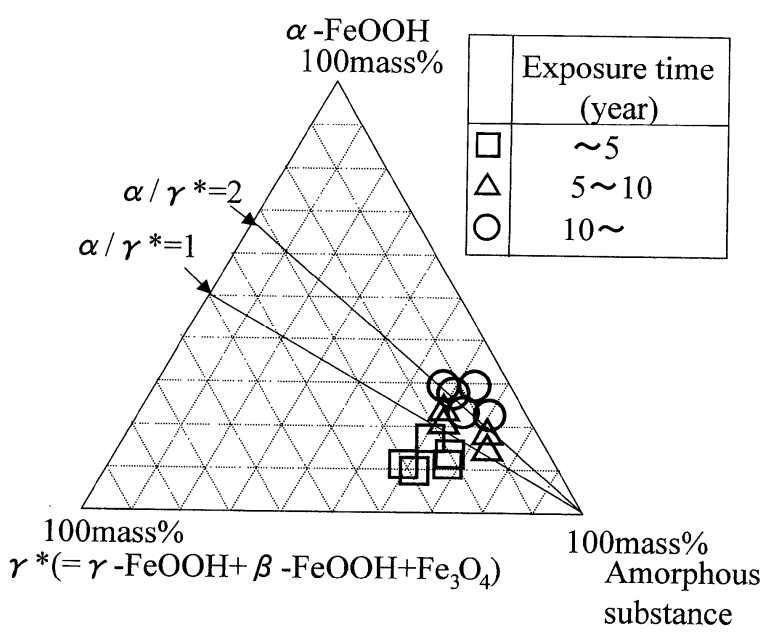

Fig. 5 Ternary diagram for the rust composition of weathering steels exposed for various exposure times.

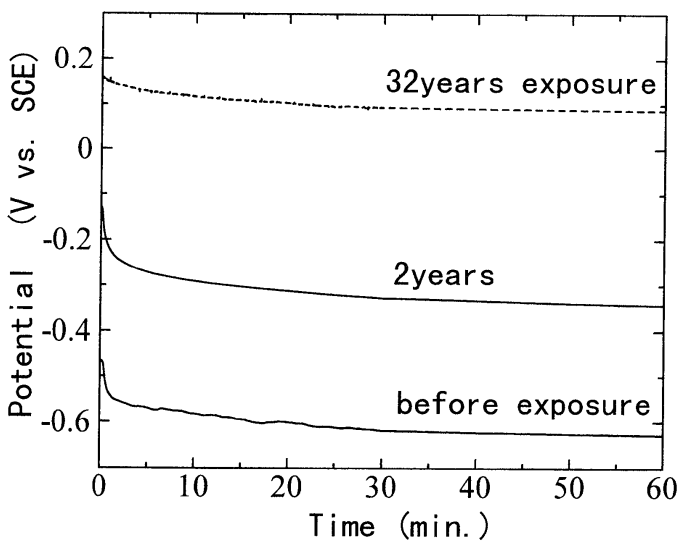

Fig. 6 Change of potential with immersion time for the weathering steels with rust layer in $0.1 \mathrm{~mol} / \mathrm{L} \mathrm{Na}_{2} \mathrm{SO}_{4}$ solution at room temperature.

増加する傾向が見られた。また，さび組成比 $\alpha / \gamma^{*}$ は経 年的に，曝露期間 5 年以下では 1 以下，曝露期間 5 年 $\sim 10$ 年では $1 \sim 2$, 曝露期間 10 年以上では 2 以上と変化 しており，長期間の曝露により保護性さびが形成するこ とに対応して $\alpha / \gamma^{*}$ が増加する傾向が見られた。

\section{2 電位によるさび層の保護性評価}

\section{2 .1 電位測定条件}

耐候性鋼さび層の保護性を評価するため，一般に電気 化学測定時に無関係塩としてょく使用される硫酸ナトリ ウム溶液中においてさび付き鋼材の電位測定を行った。 Fig. 6 にさび層のない曝露前, 2 年曝露および 32 年曝 露されたさび層付き耐候性鋼の $0.1 \mathrm{~mol} / \mathrm{L}$ 硫酸ナトリ ウム溶液中での電位の時間変化を示す. 電位は時間とと もに卑化し，浸漬後約 30 分経過すると電位はほほ定常 值に達することがわかった。 30 分後の電位は曝露前, 2 年嚗露， 32 年嚗露の順に貴となっており, 電位は曝 露時間依存性を有することがわかる。このことは, Fig. 1 に示した大気曝露時間の経過とともに腐食速度が低下 する傾向にあることに対応して，電位が貴となる傾向に

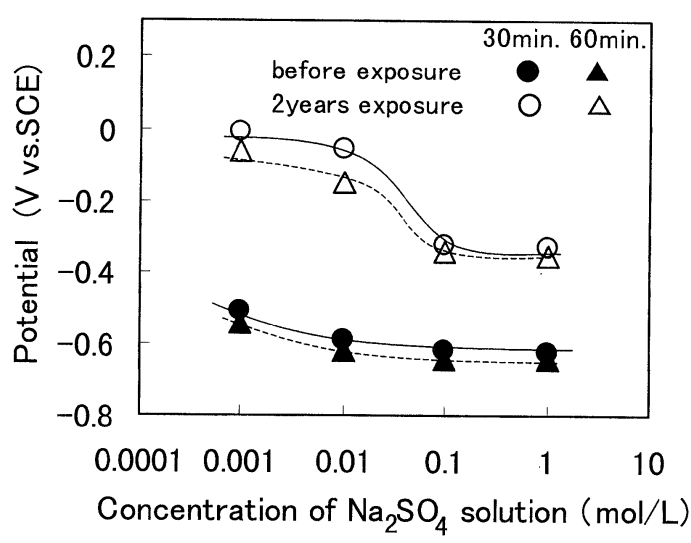

Fig. 7 Relationship between the concentration of $\mathrm{Na}_{2} \mathrm{SO}_{4}$ solution and potential of weathering steels with rust layer after immersion for 30 and 60 minutes.

あることを意味し，電位がさび層の保護性評価に使用で きる可能性が示唆される．また，浸漬直後の電位の時間 変化は, 電位の比較的卑な曝露前および 2 年曝露耐候性 鋼については大きいが，電位の比較的貴な 32 年嚗露材 については小さい.このような 2 年曝露材と 32 年曝露 材の挙動の差はさび層の安定性を反映し，32 年曝露材 が比較的安定であるのに対し， 2 年曝露材は硫酸ナトリ ウム溶液中でさびが不安定で何らかの反応を抗こしやす いことによると考えられる．Fig. 7 は電位に及涩す硫酸 ナトリウム濃度の影響を示したものである。濃度が高く なるにつれ電位は卑化する傾向にあり， $0.1 \mathrm{~mol} / \mathrm{L}$ 以上 の濃度では電位の值がほぼ一定となった。また，0.01 $\mathrm{mol} / \mathrm{L}$ 以下の濃度では 30 分後と 60 分後の電位とで差 が見られ, $0.01 \mathrm{~mol} / \mathrm{L}$ 以下の濃度では 30 分では定常值 に達していない場合がある。これらのことから，以降の 電位測定はすべて $0.1 \mathrm{~mol} / \mathrm{L}$ 硫酸ナトリウム溶液を用 い，30 分後の電位をもってサンプル間の比較を行うこ ととした.

\section{2 .2 電位の経年変化}

さび層の保護性と電位との関係をさらに詳しく調査す るため, 大気嚗露時間を変化させた耐候性鋼の電位測定 を行った。また，一部の普通鋼についても電位を測定し た. Fig. 8 亿各種曝露材についての電位の経年変化を示 す. 曝露前の耐候性鋼の電位は, 約 $-0.7 \mathrm{~V}$ (vs. SCE) であるが， 1 年程度の曝露で約 $-0.4 \mathrm{~V}$ (vs. SCE) まで 貴化し，その後経年的に緩やかに変化する. そして，5 $\sim 10$ 年後から再び著しく電位は貴化し， 30 年以上もの 長期間の曝露により $-0.3 \mathrm{~V}$ (vs. SCE) 以上の貴な電位 を示すようになる。また，普通鋼については，30 年以 上の長期間曝露されたものも $-0.45 \mathrm{~V}$ (vs. SCE) 程度 の比較的卑な電位しか示さなかった。このことは Fig. 1 で普通鋼は 30 年以上経過しても耐候性鋼に比べ腐食 速度が大きく，さび層の保護性がかなり劣っていること に対応しているものと考元られる。また，耐候性鋼にお いてー0.3 V (vs. SCE) より貴な電位を示すものについ ての断面偏光顕微鏡観察からは, Fig. 2 亿示すものと同 様, さび層は消光層からなる内層と偏光層からなる外層 の二層構造を呈していることから，電位はさび層の構造 と密接に関連していることがわかる。 


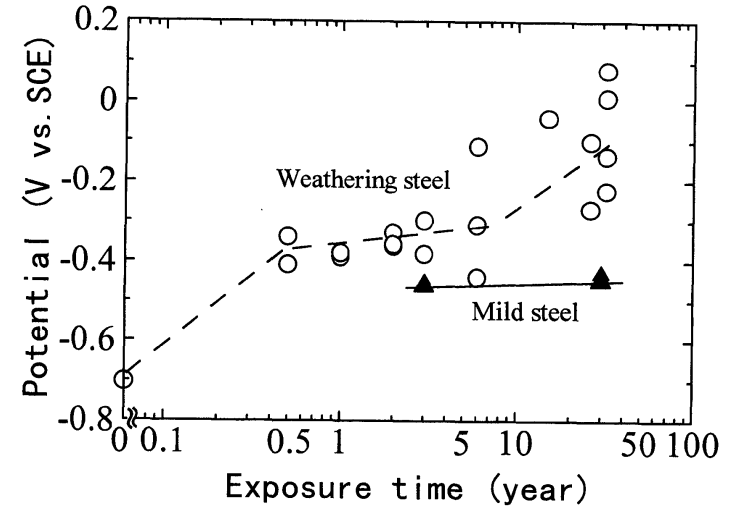

Fig. 8 Relationship between exposure time and potential of weathering steels after immersion for 30 minutes in 0 . $1 \mathrm{~mol} / \mathrm{L} \mathrm{Na}_{2} \mathrm{SO}_{4}$ solution.

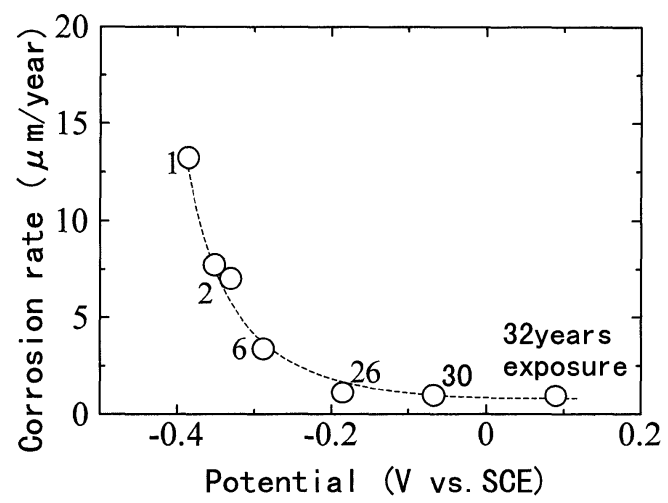

Fig. 9 Relationship between potential in $0.1 \mathrm{~mol} / \mathrm{L} \mathrm{Na}_{2} \mathrm{SO}_{4}$ solution and corrosion rate of weathering steels.

次に，Fig. 1 に示した耐候性鋼における腐食量の経年 変化の曲線の勾配より各々の曝露期間における腐食速度 を求め, 各曝露材の $0.1 \mathrm{~mol} / \mathrm{L}$ 硫酸ナトリウム溶液中 での浸漬 30 分後の電位に対してプロットした結果が Fig. 9 である。電位が貴なほど腐食速度が低下する傾向 が見られ, $-0.3 \mathrm{~V}$ (vs. SCE) 程度より貴な電位を示す ものでは腐食速度が数 $\mu \mathrm{m} /$ year 以下と非常に小さくな ることがわかった。このように，電位と腐食速度には相 関性があり，電位が貴化することとさび層の保護性の増 大とが対応していることが明らかとなった。

\section{2 .3 電位とさび組成の関係}

前節においてさび構成物質の経年変化について述べた が，ここではさびの組成と電位の関係について述べる。 Fig.10 はさび組成比 $\alpha / \gamma^{*}$ と電位の関係を示したもの である.さび組成比 $\alpha / \gamma^{*}$ が大きくなるほど電位が貴と なる傾向を示している．またこの図より，5年以下， 5 〜 10 年, 10 年以上の 3 つの領域において, それぞれさ び組成比 $\alpha / \gamma^{*}$ と電位 $(E)$ は, $\alpha / \gamma^{*} \leqq 1$ に対して $E \leqq-0.35 \mathrm{~V}$ (vs. SCE)， $1<\alpha / \gamma^{*} \leqq 2$ に対して -0.45 $\mathrm{V} \sim-0.3 \mathrm{~V}$ (vs. SCE), $\alpha / \gamma^{*}>2$ に対して $E>-0.3 \mathrm{~V}$ (vs. SCE) という対応関係にあることがわかった。こ のように，電位はさび組成と密接に関係しており，評価 法として適当であることが判明した．以上に述べたよう に, 電位はさび層の構造, 組成および防食性とも密接に 関連し，さび層の保護性を反映した特性值として，その

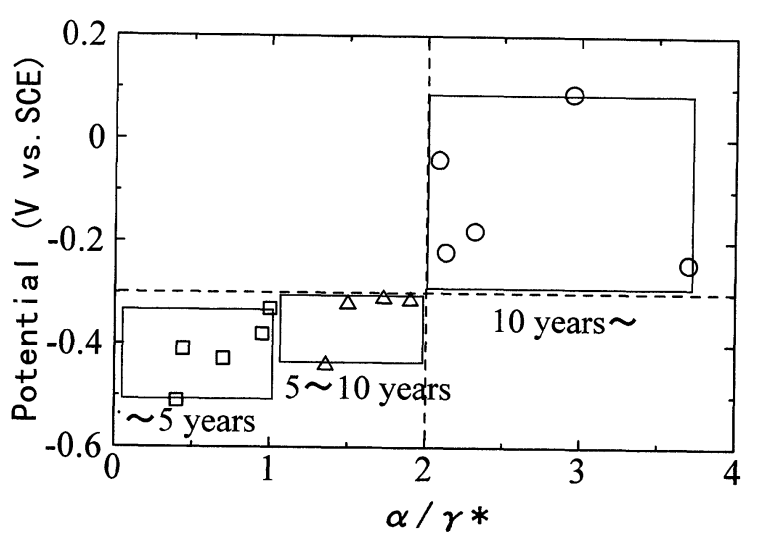

Fig. 10 Relationship among $\alpha / \gamma^{*}$ ratio, exposure time and potential of weathering steels after immersion for 30 minutes in $0.1 \mathrm{~mol} / \mathrm{L} \quad \mathrm{Na}_{2} \mathrm{SO}_{4}$ solution $\left(\alpha: \alpha^{-}\right.$ $\left.\mathrm{FeOOH}, \gamma^{*}: \gamma^{-} \mathrm{FeOOH}+\beta-\mathrm{FeOOH}+\mathrm{Fe}_{3} \mathrm{O}_{4}\right)$.

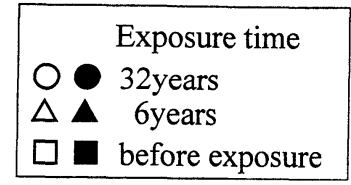

open:aerated solid:deaerated

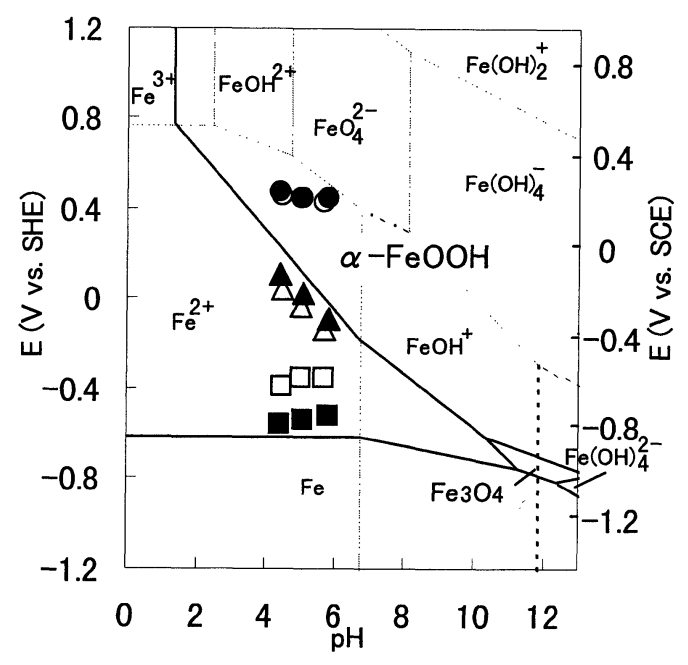

Fig. 11 Potential of weathering steels with rust layer after immersion in $0.1 \mathrm{~mol} / \mathrm{L} \mathrm{Na}_{2} \mathrm{SO}_{4}$ solution for 30 minutes in the potential-pH diagram for $\mathrm{Fe}-\mathrm{H}_{2} \mathrm{O}$ system at activity of dissolved ion species of $10^{-6}$ $\mathrm{mol} / \mathrm{L}, 25^{\circ} \mathrm{C}$.

保護性の簡易な評価法として適切と考えられる.

\section{3 さび付き鋼材における電位の意味}

さび付き鋼材における電位の意味について，三澤によ つて作成された $\mathrm{Fe}-\mathrm{H}_{2} \mathrm{O}$ 系の電位- $\mathrm{pH}$ 図 ${ }^{15)}$ を用いて考 察する. Fig.11 は，大気曝露前， 6 年曝露および 32 年 曝露耐候性鋼について，大気開放下および Ar を溶液中 に吹き込んだ脱気条件下で， $0.1 \mathrm{~mol} / \mathrm{L}$ 硫酸ナトリウム 単味溶液およびそれに硫酸を添加することにより $\mathrm{pH}$ を 低下させた溶液中における電位を電位- $\mathrm{pH}$ 図上に重ね あわせた結果である。ここで, 32 年曝露材は先に示し たように腐食速度がわずかでさび層も二層構造を呈し， 


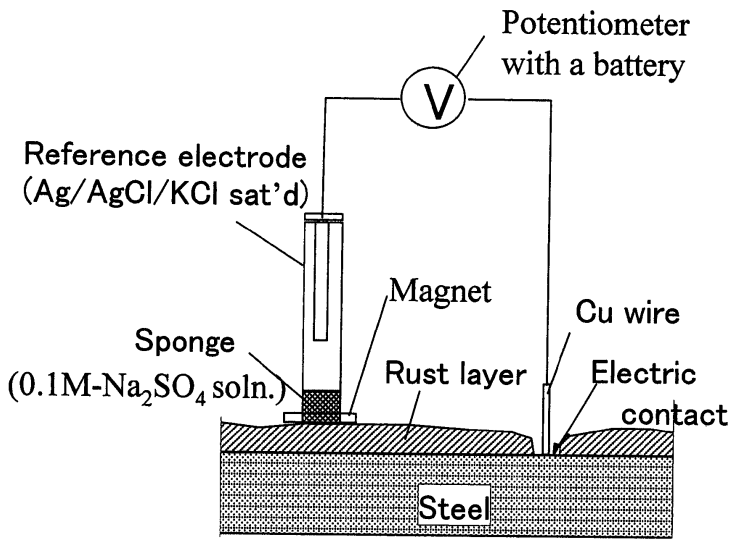

Fig. 12 Measuring potential assembly.

さび層の保護性が高いもので， 6 年曝露材は 32 年曝露 材に比べさび層の保護性が低いものの代表としてそれぞ れ選定した。

曝露前の耐候性鋼の大気開放下での電位は約 $-0.7 \mathrm{~V}$ (vs. SCE) で $\mathrm{Fe}^{2+}$ 安定域に， 6 年曝露材は約 $-0.3 \mathrm{~V}$ (vs. SCE) で $\mathrm{Fe}^{2+}$ と $\alpha-\mathrm{FeOOH}$ の安定域の境界付近 に, 32 年曝露材は $\alpha-\mathrm{FeOOH}$ の安定域にそれぞれ位置 する.また, 溶液の $\mathrm{pH}$ が低下すると, 6 年曝露材は $\mathrm{Fe}^{2+}$ と $\alpha-\mathrm{FeOOH}$ の境界に沿って電位が貴化する。

さらに, Ar 脱気条件下で電位を測定した場合，大気 開放条件下で測定した場合に比べ曝露前の耐候性鋼では 大きく電位が卑化した一方で， 6 年曝露材および 32 年 懪露材については電位はほとんど変化しなかった。この ことは, 曝露前の耐候性鋼においてはカソード反応に対 する寄与の大きい酸素の還元反応が $\mathrm{Ar}$ 脱気により抑制 され，その結果電位が大きく卑化した一方で， 6 年およ び 32 年曝露材においてはカソード反応がさび層自体の 還元反応が主で, 酸素の還元反応の寄与は小さいことを 意味すると考えられる.

以上のことより, 内層さびが $\alpha-\mathrm{FeOOH}$ を主体とす る 32 年曝露材の電位が, $-0.3 \mathrm{~V}$ (vs. SCE) 以上の貴な 值を示し, かつ腐食速度も極めて低いことは, さび層が $\alpha-\mathrm{FeOOH}$ の安定な電位領域に位置し, アノード反応 が著しく抑制されかつさび層が還元されにくい状態にあ ることと対応しているものと考えられる. 一方で, -0.3 $\mathrm{V}$ (vs. SCE) 以下では $\gamma-\mathrm{FeOOH}$ が比較的多く存在し, それらが例えば次式により $\mathrm{pH}$ に依存して還元される領 域にあることによるものと考えられる。

$$
\gamma-\mathrm{FeOOH}+3 \mathrm{H}^{+}+\mathrm{e} \longrightarrow \mathrm{Fe}^{2+}+2 \mathrm{H}_{2} \mathrm{O}
$$

あるいは

$$
3 \gamma-\mathrm{FeOOH}+\mathrm{H}^{+}+\mathrm{e} \longrightarrow \mathrm{Fe}_{3} \mathrm{O}_{4}+2 \mathrm{H}_{2} \mathrm{O}
$$

\section{5 実橋梁への適用可能性}

電位測定によるさび層の保護性のその場評価法の実橋 梁への適用について検討した. その場測定では，簡易な 装置と短時間での測定が不可欠である. 先に示した方法 は, 硫酸ナトリウム溶液に浸漬後 30 分経過したときの 電位を測定するもので，その場測定法としては時間がか かりすぎ, 現場での測定には不向きである. そこで, 電 位測定システムとして Fig.12に示す簡易装置を試作し

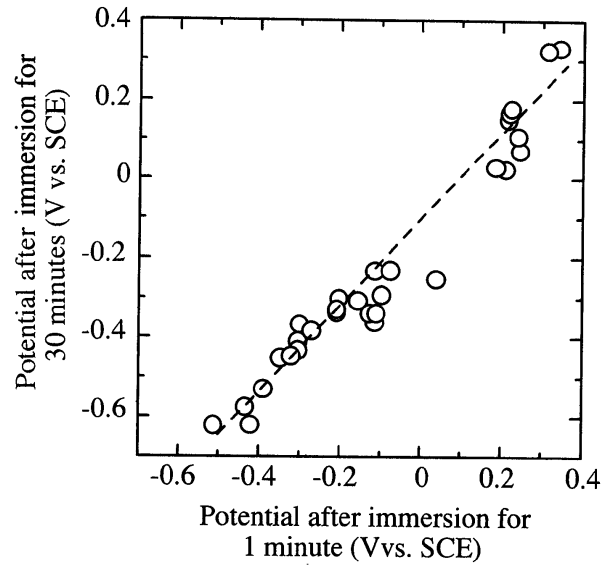

Fig. 13 Relationship between potentials after immersion for 30 minutes and 1 minute in $0.1 \mathrm{~mol} / \mathrm{L} \mathrm{Na}_{2} \mathrm{SO}_{4}$ solution.

た.その構成は，プラスチック製で破損しにくい外筒を 有する参照電極 $(\mathrm{Ag} / \mathrm{AgCl}, \mathrm{KCl}$ 飽和） と乾電池を電源 とする電位差計，および溶液を含ませたスポンジからな る.この装置を用いて測定した 1 分後の電位と 30 分後 の電位の関係を Fig.13 に示す. 1 分後と 30 分後の電位 には直線的な相関があり，このことより 1 分の短時間測 定での評価が可能であることがわかった。ささび層の保護 性の目安である 30 分測定での-0.3 V (vs. SCE) は, 1 分測定では一0.15 V(vs. SCE) に相当する. 以上のこ とより，耐候性鋼のさび層の保護性のその場評価法とし て，電位測定による方法は実橋梁への適用が可能であ $ろ^{16) 17)}$.

\section{4. 結訔}

工業地帯で大気嚗露した耐候性鋼を用い，さび層の保 護性の電位による評価について検討するとともに，さび 層の構造やさび構成物質との関連についても調査した結 果，以下のことが明らかとなった。

（1）耐候性鋼においては，曝露期間が長くなり腐食 速度が低下することに対応して電位が貴化する傾向にあ る.

（2）電位はさび層の構造を反映し，さび層が消光層 からなる内層と偏光層からなる外層の二層構造を呈して いるものについては, $-0.3 \mathrm{~V}$ (vs. SCE) 以上の貴な電 位を示す。

（3）電位はさび組成とも関係し， $\alpha-\mathrm{FeOOH}$ 量が増 加するほど電位が貴化する傾向にある.さらに電位は, さび組成比 $\alpha / \gamma^{*}\left(\alpha: \alpha-\mathrm{FeOOH}, \gamma^{*}: \gamma^{-\mathrm{FeOOH}+} \beta-\right.$ $\left.\mathrm{FeOOH}+\mathrm{Fe}_{3} \mathrm{O}_{4}\right)$ と良好な相関性があり， $\alpha / \gamma^{*}$ の増大 とともに電位は貴化する。

（4）以上のことから電位によりさび層の保護性の評 価が可能で, $-0.3 \mathrm{~V}$ (vs. SCE) 以上の貴な電位を示す さび層は耐候性に優れる。

なお，本研究を行うにあたり，ラマン分光分析をして いただいた住友金属工業(株)総合技術研究所，松田恭司 氏に感謝します。 
参 考 文 献

1）JIS H 8617 ニッケル及びニッケルークロムめっき 付属 書 3 (1991).

2) H.Kihira, S. Ito, T. Murata: Corrosion, 45, 347 (1989).

3）紀平 寛：日本溶接学会誌，63，435（1994）.

4）岡田秀彌, 細井祐三, 湯川憲一, 内藤浩光：鉄と鋼, 55, 355 (1969).

5) 長野博夫, 山下正人, 鈴木重夫：材料，44，1314 (1995).

6）山下正人, 幸 英昭, 長野博夫：材料とプロセス, 10 , 556 (1997).

7）鹿島和幸, 岸川浩史, 幸 英昭：材料とプロセス，11, 1108 (1998).

8）鹿島和幸, 岸川浩史, 幸 英昭, 原 修一, 神谷光昭 (K. Kashima, H. Kishikawa, H. Miyuki, S. Hara and M. Kamiya): 材料と環境'99講演集 (Proc. JSCE Materials and Environments 1999)，p. 25，腐食防食協 会 (JSCE) (1999).

9）幸 英昭：検查技術，4，45（1999）。

10）岩田多加志, 中山武典, 泊里治夫，竹内俊二郎，横井利 雄, 森 一弘 (T. Iwata, T. Nakayama, H. Tomari, S.
Takeuchi, T. Yokoi and K. Mori)：腐食防食 '95 講演 集 (Proc. JSCE Corrosion '95), p. 346, 腐食防食協会 (JSCE) (1995).

11）岸川浩史, 幸 英昭, 原 修一, 神谷光昭, 山下正人 (H. Kishikawa, H. Miyuki, S. Hara, M. Kamiya and M. Yamashita)：第 45 回材料と環境討論会 (Proc. 45th Japan Conf. Materials and Environments), p. 415，腐食防食協会（JSCE）（1998）。

12）山下正人, 幸 英昭, 長野博夫, 三沢俊平 (M. Yamashita, H. Miyuki, H. Nagano and T. Misawa): 材料と 環境 [Zairyo-to-Kankyo (Corros. Eng.)], 43, 26 (1994).

13）三澤俊平, 山下正人, 松田恭司, 幸 英昭, 長野博夫： 鉄と鋼, 79, 69 (1993).

14) M. Stratmann and K. Hoffmann, : Corros. Sci., 13, 659 (1993).

15) T. Misawa: Corros. Sci., 13, 659 (1993).

16）鹿島和幸, 岸川浩史, 幸 英昭, 原修一, 神谷光昭： 材料とプロセス，12，427 (1998).

17）原 修一，鹿島和幸，岸川浩史，幸 英昭，三澤俊平： 鉄と鋼，（投稿中）。

(Manuscript received September, 1999; in final form November 11, 1999) 